Boise State University

ScholarWorks

Geosciences Faculty Publications and

Presentations

Department of Geosciences

$5-2015$

Vegetative and Climatic Controls on Holocene Wildfire and

Erosion Recorded in Alluvial Fans of the Middle Fork Salmon River, Idaho

Kerry Riley

Utah State University

Jennifer Pierce

Boise State University

Grant A. Meyer

University of New Mexico 


\title{
Vegetative and Climatic Controls on Holocene Wildfire and Erosion Recorded in Alluvial Fans of the Middle Fork Salmon River, Idaho
}

\author{
Kerry Riley* \\ Geology Department \\ Utah State University \\ Logan, Utah \\ kerry.riley@aggiemail.usu.edu \\ Jennifer Pierce \\ Department of Geosciences \\ Boise State University \\ Boise, Idaho \\ Grant A. Meyer \\ Department of Earth \& Planetary Sciences \\ University of New Mexico \\ Albuquerque, New Mexico
}

\begin{abstract}
The Middle Fork Salmon River watershed spans high-elevation mixed-conifer forests to lowerelevation shrub-steppe. In recent decades, runoff from severely burned hillslopes has generated large debris flows in steep tributary drainages. These flows incised alluvial fans along the mainstem river, where charcoal-rich debris-flow and sheetflood deposits preserve a record of latest Pleistocene to Holocene fires and geomorphic response. Through deposit sedimentology and ${ }^{14} \mathrm{C}$ dating of charcoal, we evaluate the processes and timing of fire-related sedimentation and the role of climate and vegetation change. Fire-related deposits compose $~ 66 \%$ of the total measured fan deposit thickness in more densely forested upper basins versus $\sim 33 \%$ in shrubsteppe-dominated lower basins. Fires during the middle Holocene ( 8000 - $5000 \mathrm{cal}$ yr BP) mostly resulted in sheetflood deposition, similar to modern events in lower basins. Decreased vegetation density during this generally warmer and drier period likely resulted in lowerseverity fires and more frequent but smaller fire-related sedimentation events. In contrast, thick fire-related debris-flow deposits of latest Pleistocene-early Holocene ( 13,500-8000 cal yr BP) and late Holocene ( $<4000$ cal yr BP) age are inferred to represent higher-severity fires, though data in the former period are limited. Widespread fires occurred in both upper and lower basins within the Medieval Climatic Anomaly (1050-650 cal yr BP) and the early Little Ice Age ca. $550 \mathrm{cal} \mathrm{yr} \mathrm{BP.} \mathrm{We} \mathrm{conclude} \mathrm{that} \mathrm{a} \mathrm{generally} \mathrm{cooler} \mathrm{late} \mathrm{Holocene} \mathrm{climate} \mathrm{and} \mathrm{a} \mathrm{shift} \mathrm{to} \mathrm{denser}$ lodgepole pine forests in upper basins by $\sim 2500 \mathrm{cal}$ yr BP provided fuel for severe fires during episodic droughts.
\end{abstract}

Keywords: Holocene, wildfire, alluvial fan, fire-related erosion, climate change, debris flow

\section{Introduction}

Climate-driven changes in vegetation structure and species distributions influence the size and severity of wildfire throughout the world (Power et al., 2008); likewise, wildfires promote changes in vegetation and ecosystem composition (Swetnam, 1993; Whitlock et al., 2003; Bowman et al., 2009). The frequency of large wildfires has increased on all vegetated continents over the last decade (Page et al., 2002; Cochrane et al., 2002; Westerling et al., 2006; Lohman et al., 2007; Forsyth and Van Wilgen, 2008; Bowman et al., 2009). Predicted increases in extreme fire events (IPPC, 2007) could greatly influence global climate, vegetation distributions, and erosion rates. In order to understand, predict, and manage for future effects of fire, it is important to understand how relations among fire, climate, and vegetation have affected the landscape in the past. Future fire regimes may reflect climate-driven 
This is an author-produced, peer-reviewed version of this article. The final, definitive version of this document can be found online at The Holocene, published by SAGE. Copyright restrictions may apply. doi: 10.1177/0959683615571423

vegetation changes and vegetation communities that have no modern analog. Climate conditions are a primary control of wildfire, therefore understanding fire regimes in the context of centennial- to millennial-scale climatic change may provide the historic context needed to understand recent increases in wildfire activity.

Fire reconstructions created using mapped fire perimeters, tree rings, and fire scars provide annual, decadal, and centennial records of fire. Charcoal in lake sediments often provides records of fire that extend back to the late Pleistocene (e.g., Brunelle et al., 2005; Power et al., 2008; Whitlock et al., 2010). Alternatively, charcoal-rich alluvial sediments are commonly deposited as a result of fire in mountain drainage basins, and can be used to reconstruct longer fire histories where perennial lakes are not present (e.g., Meyer et al., 1995). Fire-related deposit characteristics also reflect the processes and magnitude of the post-fire erosional response, and therefore provide insight into the general extent and severity of fire in small, steep basins (e.g., Meyer et al., 1995; Pierce et al., 2004; Cannon et al., 2010).

During the 1980s, large wildfires increased in severity and frequency throughout the western United States across a range of ecosystems, and middle elevation (2590-1680 m) northern Rocky Mountain forests experienced the greatest increases (Westerling et al., 2006). Fire activity has also become more synchronous across the northern Rocky Mountains (Morgan et al., 2008), where climate, not prior fire suppression and land use, has been shown to be the primary driver of increased burn areas in the late $20^{\text {th }}$ century (Westerling et al., 2006). Severe drought is a primary driver of widespread fire, including within a single summer (e.g., Balling Jr et al., 1992; Westerling et al., 2006; Heyerdahl et al., 2008), but fire regimes are also a function of fuel characteristics (e.g., vegetation density and type), which may vary over a broad range of timescales.

The Middle Fork Salmon River (MFSR) in central Idaho flows through the extensive Frank Church-River of No Return Wilderness (Figure 1); this basin provides a favorable setting for examining both modern and Holocene firerelated geomorphic processes that have been less influenced by management and land-use activities than in many western USA environments. The MFSR contains both modern and Holocene fire-related erosional events that are well preserved in charcoal-rich alluvial fan sediments. Alluvial fan catchments span a wide range of environments. The mainstem MFSR descends from moist mixed-conifer forests in the upper watershed to drier shrub-steppe along the lower canyon, and thus provides a natural climatic and ecological gradient over which spatial and temporal changes in fire activity and landscape response can be investigated. We compare the type and history of fire-related depositional events from ten small, steep tributary basins along this ecological gradient to answer these main questions: (1) How does modern and Holocene fire-related sedimentation vary over an gradient spanning montane to shrub-steppe ecosystems? (2) Have fire-related erosion events changed in processes and timing along the MFSR within the Holocene? (3) What do alluvial sediments reveal about relations among fire frequency and severity, vegetation, climate, and geomorphic response on centennial to millennial timescales?

\section{[Insert Figure 1]}

\section{$\underline{1.1 \text { Fires and Geomorphic Response }}$}

Wildfire reduces vegetation and litter cover, thus decreasing rainfall interception, infiltration rates, and surface roughness, producing an increased potential for surface runoff, erosion, and major sedimentation events for several years (e.g., Wondzell and King, 2003). Fires often produce soil water repellency, and fine-grained ash clogs pores on bare soil surfaces, reducing infiltration rates (e.g., Meyer and Wells, 1997; Shakesby and Doerr, 2006). Rapid surface runoff over smooth, erodible slopes results in sheetwash and rilling, with entrainment of large volumes of ash and fine sediment. Further sediment bulking by channel incision leads to debris flows or highly sedimentcharged floods, and flow processes may vary within a single event (Meyer and Wells, 1997; Cannon et al., 2003; Parise and Cannon, 2012). Decay of roots after 5-10 years also increases the potential for slide failures of saturated colluvium that transform into debris flows (Schmidt, 2001); however, runoff-generated debris flows and floods appear to be the most common post-fire response in the Rocky Mountains, typically during summer convective storms on moderately to severely burned slopes (Wondzell and King, 2003; Cannon et al., 2003), In the MFSR basin, field observations indicate modern debris flows were initiated by runoff generation following summer storms (Riley, 2012). Low-severity fires leave remnants of unburned vegetation and litter such that runoff generation and flow paths are discontinuous, limiting hillslope erosion and sediment yields (Lavee et al., 1995). In the Idaho 
This is an author-produced, peer-reviewed version of this article. The final, definitive version of this document can be found online at The Holocene, published by SAGE. Copyright restrictions may apply. doi: 10.1177/0959683615571423

Batholith region, postfire events commonly result in deposition on alluvial fans where steep tributaries enter larger valleys. Postfire flows may also enter mainstem river channels and result in channel damming or constriction and local aggradation (Meyer et al., 2001; Goode et al., 2012).

\section{$\underline{1.2 \text { Study Area }}$}

The mainstem MFSR has its southernmost headwaters in the Sawtooth Mountains and flows northward through the broad Salmon River Mountains to its confluence with the Main Salmon River (Figure 1). Its $\sim 7,400 \mathrm{~km}^{2}$ watershed is characterized by rugged topography with a mean hillslope gradient of $\sim 54 \%\left(\sim 28.5^{\circ}\right)$ and elevations ranging from 920-3160 m. Annual precipitation increases with elevation, from $~ 355 \mathrm{~mm}$ measured at Taylor Ranch at $1181 \mathrm{~m}$ in the lower MFSR watershed, to $\sim 840 \mathrm{~mm}$ at Deadwood Summit at $2091 \mathrm{~m}$ elevation just west of the watershed divide (Figure 1). Rain-dominated basins from 500-1500 m experience runoff throughout winter and spring, with generally lower streamflows, whereas snow-dominated basins at 2250-3250 m produce high streamflows in spring to summer (Tennant, 2010). The overall fire season extends from late April-October (Hostetler et al., 2006).

Ten small (0.2-14 $\left.\mathrm{km}^{2}\right)$ tributary sub-basins were selected for study, spanning $\sim 100 \mathrm{~km}$ of the MFSR, and ranging from densely forested headwaters to sagebrush grasslands of the lower basin (Figure 1). The sub-basins are underlain primarily by Idaho Batholith granitic rocks that produce erodible grussy colluvium (Clayton and Megahan, 1997). Five upper sub-basins lie at wetter upper elevations and are characterized by dense subalpine to mixedconifer forests, where fire is generally limited by canopy fuel moisture (Schoennagel et al., 2004). Major tree species include lodgepole pine (Pinus contorta), Douglas-fir (Pseudotsuga menziesii), and Engelmann spruce (Picea englemannii) (Steele et al., 1981). Such forests typically burn infrequently at intervals of 200-400 yr in highseverity stand-replacing fires (Schoennagel et al., 2004; Agee, 1996; Despain, 1990). At middle elevations (1700$1380 \mathrm{~m}$ ), mixed Douglas-fir and ponderosa pine stands occupy warmer south-facing slopes, whereas lodgepole pine dominates more shaded slopes (Steele et al., 1981). Five lower sub-basins are located in drier lower elevations, characterized by shrub-steppe vegetation with open Douglas-fir and ponderosa pine (Pinus ponderosa) stands. Fire history studies in similar environments suggest a mixed-severity regime dominated by surface fires of 20-30 yr return intervals, but punctuated by high-severity fires at intervals of 150-400 yr (Barrett, 1988; Arno et al., 1995; Shinneman and Baker, 1997; Brown et al., 1999; Schoennagel et al., 2004). Sagebrush (Artemisia spp.) grasslands characterize shrub-steppe environments in the lowest elevations along the MFSR (Peek, 2000). While fire return intervals have been variously estimated from 35-200 yr in such vegetation communities, the invasion of cheatgrass (Bromus tectorum) has dramatically increased fine-fuel loads and fire frequency over the last century (Baker, 2006; Bukowski and Baker, 2013). Aspect is a strong influence throughout the MFSR basin, with greater vegetation density and forest cover on north-facing slopes.

\section{Methods}

Within the ten study fans, a total of 35 stratigraphic profiles were described, and samples from 23 profiles were radiocarbon dated. An individual stratigraphic profile represents some fraction of all depositional events, as most emplace sediment over only part of the fan (e.g.,Wells and Harvey, 1987; Meyer and Wells, 1997). Therefore, two to six profiles were described within each fan, including color, field texture, depth, continuity, thickness, sorting, angularity, and a qualitative estimate of charcoal abundance. Deposits were classified as fire-related if they contained abundant charcoal and (or) were underlain by a charred litter layer marking a burned soil surface (Meyer et al., 1995). Charcoal fragments were selected for ${ }^{14} \mathrm{C}$-dating if unit characteristics supported charcoal deposition contemporaneous with the sediment, i.e., where there was no visible evidence of burrows, other bioturbation, or burning of a subsurface root.

Depositional process was inferred based on deposit characteristics defined in previous studies (Meyer and Wells, 1997; Cannon, 2001; Pierson, 2005). Debris-flow deposits are very poorly sorted with a fine-grained matrixsupported texture, and contain pebble- to boulder-sized angular clasts. Because water and fine sediment flow together in debris flows as a single fluid (Iverson, 1997), charcoal remains in the muddy matrix and is usually abundant in fire-related debris-flow deposits (Meyer and Wells, 1997). Sheetflood fan deposits contain thin beds of moderately sorted fine and coarse sand-pebble-sized particles of varying thicknesses. Overbank flood and sheetflood deposits with abundant charcoal were considered fire-related; however, charcoal is typically deposited 
This is an author-produced, peer-reviewed version of this article. The final, definitive version of this document can be found online at The Holocene, published by SAGE. Copyright restrictions may apply. doi: 10.1177/0959683615571423

only in lower-energy sites during floods, so coarse deposits often lack charcoal. Overbank flood deposits contained well-sorted fine-grained (fine sand to clay-sized) sediment, with dark layers of charcoal, and scattered larger charcoal fragments.

We classified deposits based on process in order to (1) examine the role of fire-related vs. non-fire related sediment transport to alluvial fans, (2) investigate differences in fire-related deposition between upper and lower basins, and (3) infer the severity of past fires based on the thickness and type of fire-related deposit. Deposit thicknesses are reported as a mean and standard error. Discrete deposit thicknesses associated with debris-flow, sheetflood, and firerelated deposits were summed throughout an individual alluvial fan site, averaged among five upper and five lower basins, and then statistically compared between upper and lower basins. If the thickness distribution for the deposit type was normal and homoscedastic, then a t-test was performed to test if deposit thicknesses were significantly different between upper and lower basin alluvial fans. If distributions failed either assumption, then the nonparametric Kruskal-Wallis statistical test was performed. Fire-related debris-flow deposits were inferred to be generated from high-severity fires within contributing basins, based on observations of modern postfire events in the western USA (e.g., Cannon, 2001; Pierce et al., 2004). Sheetflood events can also occur following severe burns (e.g., Meyer and Wells, 1997), but major debris-flow deposition is unlikely after low-severity fires (Cannon and Gartner, 2005), therefore thick, charcoal-rich debris-flow deposits provide the most reliable indicator of highseverity burns.

Individual charcoal fragments $(\mathrm{n}=64)$ were ${ }^{14} \mathrm{C}$-dated, specifically targeting charred twigs and needles in order to reduce inbuilt age errors associated with dating materials that are older than the year of the fire. Twigs were identified by locating small concentric rings using a microscope. Rounded fragments indicating that charcoal had been reworked in multiple events were avoided. Samples were dated at Lawrence Livermore National Laboratory and the NSF-AMS Lab at University of Arizona. Radiocarbon dates were calibrated to calendar years before present (al yr BP, where present $=1950 \mathrm{CE}$ ) using CALIB 6.0 (Reimer et al., 2004), and the weighted mean of the calibrated probability density distribution for the age and its analytical uncertainty are reported, rounded to the nearest decade (Table 1; Telford et al., 2004).

Different charcoal ages within one deposit can result from charcoal reworked from older deposits, burning of older material such as dead wood or inner tree rings, or from bioturbation (Gavin, 2001). We dated a pair of charcoal fragments from each of 10 deposits to determine if the two samples likely represented the same fire event. If a t-test showed that the replicate sample ages were statistically indistinguishable, the same fire likely produced the two charcoal fragments, and the older sample was eliminated from the final data set to avoid exaggeration of fire peaks in the record. We also eliminated one age from the final data set where two statistically indistinguishable ages were found within one fan and likely represented the same fire in that fan's basin. Statistically indistinguishable ages from separate basins were retained, thus the record represents a composite of individual basin histories, analogous to a tree ring-based fire history assembled from multiple stands. Samples located low in a stratigraphic profile but with post-1950 ages were assumed to be from unrecognized young inset deposits within the incised channel, and post1950 ages from deposits at the top of stratigraphic profiles were considered to represent recent events.

Calibrated probability distributions for each ${ }^{14} \mathrm{C}$ age were summed (e.g., Meyer et al., 1995) to represent the firerelated sedimentation history of the MFSR, classified in three ways: (1) upper basin, (2) lower basin, and (3) all MFSR fire-related sedimentation events. These events are hereafter referred to as fires for simplicity, recognizing that only a subset of fires in a study basin will be recorded as a sedimentation event, and that a single widespread fire may be represented by dated events in multiple basins. The summed probability curves were then smoothed with a 100-year running mean. The probability curve for all MFSR fires was detrended using the method of Surovell et al. (2009) for correcting taphonomic bias associated with the loss of preservation in the geologic record through time, and lack of exposure of older sediments. While fire-related deposits as old as $\sim 13,500 \mathrm{cal} \mathrm{yr} \mathrm{BP}$ were located, the number of dated deposits decreases with time. This is in large part because of the fading record problem common in alluvial stratigraphy, where older deposits are less likely to be preserved and exposed (e.g., Meyer et al., 1995; Surovell et al., 2009; Ballenger and Mabry, 2011). This reconstruction, therefore, represents a partial record of fire occurrences, and better represents more severe fires, which more likely result in erosion and fan deposition. It also provides a more complete record of younger events, given their better exposure and preservation. With these caveats in mind, a statistical sample of fire events in the contributing watersheds was developed by dating a number of fire-related deposits. 
This is an author-produced, peer-reviewed version of this article. The final, definitive version of this document can be found online at The

Holocene, published by SAGE. Copyright restrictions may apply. doi: 10.1177/0959683615571423

[Insert Table 1 and Figure 2]

\section{Results}

\subsection{Radiocarbon Ages}

Seven out of ten replicate pairs of ${ }^{14} \mathrm{C}$-dated charcoal resulted in statistically indistinguishable $(\alpha=0.05)$ calibrated ages, suggesting that the charcoal was produced in a single fire and deposited in response to that event. Three field replicates showed statistically significant differences in age distributions at $\alpha=0.05$, suggesting the older charcoal fragment was derived (1) from reworked material, (2) from an older part of the tree (e.g., inner heartwood), or (3) from preserved dead wood. Where replicate samples gave significantly different ages, the magnitude of difference helps in assessing the cause of age discrepancies; these magnitudes were 310, 1010, and 1090 years. The two larger age discrepancies were likely a result of the incorporation of older charcoal stored in soil or alluvium into younger fire-related flows. Meyer et al. (1995) found that in Yellowstone National Park, four out of five charcoal fragments within one fire-related debris-flow deposit had statistically indistinguishable age distributions; however, in the humid Oregon Coast Range, charcoal commonly has large inherited age errors compared to alluvial deposit ages (Frueh and Lancaster, 2014).

\section{[Insert Figure 3]}

\subsection{Fire-related sedimentation chronology and depositional process}

The final data set used to reconstruct the MFSR fire history contained 49 age distributions inferred to represent discrete fires within a study basin (Figure 3). Although 64 charcoal fragments were dated (Table 1), seven field replicates showed statistically indistinguishable ages, three samples recorded a statistically indistinguishable fire from multiple profiles within the same sub-basin, and five samples were modern or post-1950 deposits. Summed probability values older than the peak in age probability at $560 \mathrm{cal}$ yr BP were detrended; we assumed the presence of deposits younger in age was not significantly impacted by lack of exposure or erosion of deposits. Ages younger than $\sim 600 \mathrm{cal}$ yr BP were found in 7 of 10 sub-basin alluvial fans, suggesting this time is not underrepresented in the record. Overall, the frequency of ages increases toward the present as shown by the steepening curve in Figure 3 .

We measured 398 discrete deposit thicknesses within 35 stratigraphic profiles from ten alluvial fans (Supplemental Material Figure 2 and 3). We interpreted all deposits as sourced from the tributary channel. Fire-related deposits comprised significantly greater total fan thicknesses in upper basin fans compared to lower basin fans. The mean thickness of debris flow deposits was similar between upper and lower basins; however, the fraction of debris-flow deposits that were fire-related was greater in upper basins compared to lower basins. Debris-flow deposits were significantly thicker than sheetflood deposits. Sheetflood deposits comprised significantly less of the total upper basin fan deposits than lower basin fan deposits, but more sheetflood deposits were classified as fire-related in upper basins than lower basins. The thickness of sheetflood packages ranged from 2 centimeters to 2 meters, with a thinner median sheetflood deposit thickness in upper basins compared to lower basins.

Thick fire-related debris flows were produced in upper basins throughout the Holocene, while debris-flow deposits dated in lower basins were restricted to the early and late Holocene (Figure 4). Lower basin debris-flow activity was high 4000-2000 and 600-100 cal yr BP, while sheetfloods were the dominant process depositing sediment onto lower-basin alluvial fans between 7 and $5 \mathrm{ka}$ (where $\mathrm{ka}=1000$ calibrated calendar years before 1950). Sheetfloods represent 5 of 8 dated deposits between 8 and $5.5 \mathrm{ka}$. These sequences of thin, fine gravel and sand deposits represent multiple frequent, small erosional events.

[Insert Figure 4] 
This is an author-produced, peer-reviewed version of this article. The final, definitive version of this document can be found online at The Holocene, published by SAGE. Copyright restrictions may apply. doi: 10.1177/0959683615571423

\section{Discussion}

\subsection{Spatial Variability in Fire-related Geomorphic Response}

Overall, fire-related sedimentation is responsible for $50 \%$ of the total measured thickness of Holocene fan deposits along the MFSR. Fire has thus played an important role in hillslope erosion and fan deposition, and while buffered by fan storage, in sediment supply to the river system as well. The relative geomorphic importance of fire also varies markedly across the study area, as fire-related deposits make up $66 \%$ of the total measured thickness of alluvial fan deposits in the upper study basins, but only $33 \%$ of the total deposit thickness in the lower basins.

We attribute the lesser relative importance of fire-related deposition on lower basin alluvial fans to two primary factors. First, burning of sparse rangeland shrubs and grasses produces a relatively minor amount of small charcoal fragments that are less likely to be identifiable and preserved after transport, and therefore yields a weaker fire signal in the stratigraphic record. A similar relationship is found in lake sediment studies, where a stronger fire signal is associated with greater biomass within contributing basins (Whitlock et al., 2004; Marlon et al., 2006). Also, modern burn severity data suggests that recent severe fires burned less total area in lower basins, thus producing less total charcoal. Second, lower vegetation cover on xeric lower basin hillslopes makes these basins more susceptible to erosional events in the absence of fire. Sparse hillslope vegetation promotes more frequent surface runoff events (Lavee et al., 1995) without the requirement of severe fire as a catalyst. This was likely a stronger control prior to the arrival and spread of cheatgrass (Bromus tectorum) into the region in the late 1800s (Peek, 2000), a species that creates a more continuous ground cover than native sagebrush and bunchgrass communities, but is much more prone to severe fire (Stewart and Hull, 1949). Modern sheetflood deposits also have a stronger association with rangeland environments than forests in central Idaho (Meyer et al., 2001; Nelson and Pierce, 2010; Weppner et al., 2013).

Sheetflood deposits make up a greater percentage of alluvial fan thickness in MFSR lower basins than in upper basins, and modern sheetflood deposits were only observed in the lower basin. Studies of fire-related deposits from the nearby South Fork Payette River also indicate that sheetfloods are more commonly generated on south-facing and (or) lower-elevation, rangeland hillslopes (Meyer and Pierce, 2003; Pierce et al., 2004). This suggests that vegetation type and density may play an important role in sedimentation processes; specifically, sheetfloods are more likely to emanate from less-densely vegetated and unburned basins, or those burned at low severity, whereas debris flows are more characteristic of severely burned forested basins. While fire-related debris flows typically produce greater sediment yields than non-fire-related sheetfloods, Meyer et al. (2001) found that a large sheetflood event from an unburned rangeland basin produced a sediment yield similar to a nearby burned previously forested basin following a major winter rain-on-snow event in central Idaho. Unlike most postfire events, however, erosion in both the South Fork Payette River basins in this particular event resulted from prolonged rain-on-snow saturation of colluvium that caused slide failures, rather than by surface runoff and progressive sediment bulking of high discharges. In both burned and unburned basins, the colluvial slide failures produced greater sediment volumes from slopes than is typical of runoff-generated events (Meyer, 2004).

\subsection{Relation to Regional Holocene Climate and Vegetation}

We evaluated the MFSR fire-related sedimentation record in relation to proxy records of Holocene climate, vegetation change, and fire in the Northern Rocky Mountain region (Figure 1). Given the large elevation-related contrasts in modern climate between the mesic, densely forested upper basins and the more xeric, shrub-steppedominated lower basins in the MFSR, it is reasonable to assume that these general differences in vegetation and associated fire regimes have persisted over the Holocene. Pollen records from the Sawtooth Mountains (Whitlock et al., 2010), however, suggest that the modern lodgepole pine-dominated forests of the upper basins were established as recently as 2.6 ka (Whitlock et al., 2010). Also, pollen and charcoal variations in lake sediments in the Bitterroot Mountains suggest that fire regimes are more similar across ecological gradients today than during most of the Holocene (Brunelle et al., 2005). Therefore, vegetation types and densities in both lower and upper basins have likely varied with both Holocene climate changes and migrations of tree species (Marlon et al., 2006; Whitlock et al., 2010).

\section{[Insert Figure 5]}




\subsection{Latest Pleistocene-Early Holocene Wildfire and Climate (13.5-7 ka)}

The oldest fires and associated sedimentation in the MFSR are recorded in debris-flow deposits dating to 13.5, 11.5, and 9-8 ka. While limited exposure of these oldest fan deposits precludes detailed inferences about fireclimate relations, it is notable that they are preserved, and the thick debris-flow deposits suggest that fire was an important factor in sediment delivery to fans during the Pleistocene-Holocene transition. While not widely exposed, thick debris-flow deposits in both upper and lower basins (Supplemental Material Figure 2) suggest high severity fires. The dates are very broadly consistent with times of elevated fire activity across North America at 13.9, 13.2, and $11.7 \mathrm{ka}$, which have been linked to rapid climate change (Marlon et al., 2009). During this major climatic transition, forests in the Bitterroot Mountains north of the MFSR changed from alpine meadows and open stands of spruce to dense pine and Douglas-fir forests (Brunelle et al., 2005), and between 11 and $9.5 \mathrm{ka}$, forests in the Sawtooth Mountains and surrounding region shifted from open spruce-pine parklands to lodgepole pine-dominated stands (Figure 5; Whitlock et al., 2010). Northern Rocky Mountain proxy records suggest that latest Pleistoceneearly Holocene climate was colder than present, and that temperature and precipitation were more variable (Figure 5; Davis et al., 2002; Brunelle et al., 2005; Whitlock et al., 2010). Summer insolation was increasing until 9 ka, however, resulting in generally higher summer temperatures, increased evapotranspiration, and suppressed summer precipitation (Bartlein et al., 1998; Whitlock et al., 2010). Overall, the increased potential for summer drought combined with the development of denser, fire-prone lodgepole pine stands may have the encouraged high-severity fires in the MFSR around the Pleistocene-Holocene transition.

\subsection{Middle Holocene Wildfire and Climate (7-4 ka)}

Greater exposure provided for more fire-related deposits to be dated in the middle Holocene compared to the preceding period. The earliest cluster of ages in the MFSR record exists at about $6.5 \mathrm{ka}$, where four ages represent fire-related sheetflood events in the lower basin (Figures 3 and 5). These events coincide with the onset of a period characterized by drought in the Sawtooth Mountains (Whitlock et al., 2010). A similar sequence was observed in a South Fork Payette River fan, where thin sheetflood deposits dated at 7400-6600 cal yr BP indicated numerous small fire-related sedimentation events at $33-80 \mathrm{yr}$ intervals in the associated basin (Meyer et al., 2001). During the middle Holocene ( 7-4 ka), low lake levels throughout Rocky Mountains (Shuman et al., 2009), warmer taxa in the regional pollen record (Brunelle et al., 2005; Whitlock et al., 2010), and low variability in stable isotope values in soils along the lower Salmon River (Davis et al., 2002) suggest climate was generally drier, warmer, and more stable (Figure 5). In the Sawtooth Mountains, open Douglas-fir forests and sagebrush steppe inferred from pollen data also indicate relatively warm and dry conditions between 8.4 and 6 ka (Whitlock et al., 2010). These proxy records suggest that warmer and drier climate resulted in a regime of more frequent, lower-severity fires in the middle Holocene.

It is notable that no fire-related sedimentation events date from about 5 to 4 ka in the MFSR, given the number of fires recorded in preceding and following periods. Soil and alluvial charcoal records in the Sawtooth Mountains (Svenson, 2010) and South Fork Payette River (Pierce et al., 2004) also suggest relatively low fire activity and severity at this time, though data are sparse. Fire-related sedimentation was quite active, however, in an overlapping period from 5.4 to $4.4 \mathrm{ka}$ in the moister, high-elevation lodgepole pine forests of Yellowstone National Park (Meyer et al., 1995). Also, a peak in fire-related sedimentation was recorded in rangelands of southwestern Idaho 4.4-4 ka (Nelson and Pierce, 2010). This suggests that warm and dry middle Holocene climate promoted high-severity burns and major fire-related sedimentation in the dense lodgepole pine-dominated forests in Yellowstone, but yielded a spatially variable response in the more open, fuel-limited lower-elevation forests and rangelands in Idaho.

\subsection{Late Holocene Wildfire and Climate (4 - $0.2 \mathrm{ka})$}

Like most such records, the MFSR history of fire and sedimentation is most complete after 4 ka (Figure 5). Consistent exposure and a relatively large number of ages provide the best opportunity to examine relations among fire, vegetation, climate, and geomorphic response. Periods of approximate synchroneity of fires across the study area can be defined as times when multiple $(\geq 2)$ sub-basins contain deposits with statistically indistinguishable charcoal ages (mean pooled age 2-sigma confidence interval). Such periods exist at 3830-3630, 2840-2620, 23402140, 1860-1720, 1610-1510, 1200-1050, 940-790, 570-320, and 260-0 cal yr BP and are marked by the highest peaks in the summed probability distributions for fire-related sedimentation ages (Figure 5). Eight out of these nine 
This is an author-produced, peer-reviewed version of this article. The final, definitive version of this document can be found online at The Holocene, published by SAGE. Copyright restrictions may apply. doi: 10.1177/0959683615571423

periods of inferred widespread fire burned both upper and lower sub-basins. Five of these eight periods (3830-3630, 2840-2620, 2340-2140, 570-320, and 260-0 cal yr BP) produced large fire-related debris flows in upper and lower basins.

Regional studies suggest that late Holocene climate was generally cooler, wetter, and more variable compared to the middle Holocene. Mesic vegetation increased along the lower Salmon River (Davis et al., 2002), pine expanded throughout the Northern Rocky Mountains 3.5 ka (Whitlock et al., 2008), and modern forest compositions were established $\sim 3$ ka in the Bitterroot Mountains (Brunelle et al., 2005). Modern conifer forests including abundant lodgepole pine were established $2.6 \mathrm{ka}$ in the Sawtooth Mountains, heightening the potential for stand-replacing fires (Whitlock et al., 2010). These data combine to indicate that overall cooler and effectively wetter conditions allowed the development of denser, less fire-resistant forest stands, especially at higher elevations, increasing the probability of extensive severe fires in episodic droughts.

Despite a generally cooler and moister climate, the late Holocene also featured extended periods of relatively warm and dry climate, most notably during the Medieval Climatic Anomaly (MCA) 1050-650 cal yr BP. The MCA stands out in many western North American climate records as a generally warmer period with high climate variability that encompasses several severe multidecadal droughts (Stine, 1994; Cook et al., 2004; Cook et al., 2007). In the MFSR, eight fire-related events date from 940-790 cal yr BP across the study area, and are particularly evident in upper, more densely forested basins. Peaks in fire and associated debris-flow activity are also prominent at this time in the nearby Sawtooth Mountains (Svenson, 2010; Whitlock et al., 2010) and South Fork Payette River (Pierce et al., 2004), as well as in Yellowstone National Park, where the high-elevation lodgepole pine-dominated forests experience widespread fire mainly during severe drought (Meyer et al., 1995). Fires appear to have been particularly severe and extensive in such dense, high-elevation stands, where canopy moisture tends to prevent fire spread except in unusually severe drought. In contrast, lower-elevation rangeland-dominated environments of the lower MFSR and Wood Creek in southwestern Idaho (Nelson and Pierce, 2010) show less activity at this time, with no large fire-related debris flows in the lower MFSR, suggesting that prolonged droughts limited fuels and fire extent and severity in these more xeric environments.

Extensive severe fires require high fuel loads combined with severe or prolonged drought. Fires burned over a wide range of ecosystems in the MFSR region in 2000 and 2007, and were followed by large debris flows (Riley, 2012). These recent fires, which may be analogs for the MCA burns, were promoted by warmer spring and summer temperatures and severe summer drought (e.g., Westerling et al., 2003; Morgan et al., 2008; Pierce and Meyer, 2008). It may be that the cooler and wetter decades of the mid-twentieth century combined at least locally with fire suppression to increase forest density for recent severe fires (Morgan et al., 2008). It may also be that colder and effectively wetter conditions over the preceding few centuries (i.e., the later Little Ice Age) allowed lodgepole-pine stands at higher elevations to become denser. Although anthropogenic fire suppression was not a factor in the MCA, and modern summer temperatures may already exceed those of Medieval time (Woodhouse et al., 2010), we infer that conditions similar to those associated with modern severe fires were responsible for widespread fires in drought episodes of the late Holocene. Likewise, Pierce and Meyer (2008) hypothesized that in the Medieval Climatic Anomaly, multidecadal wet intervals promoted development of dense forest stands, followed by long and severe droughts that drove large, severe fires across a range of forest types in the South Fork Payette River basin.

Following the warmer MCA, glaciers advanced in Northern Rocky Mountains during the Little Ice Age (LIA) 650100 cal yr BP (Carrara, 1989; Luckman, 2000), and colder climate conditions were recorded throughout the Northern Hemisphere (e.g., Grove, 1988; Pollack et al., 1998; Esper et al., 2002; Mann et al., 2009). Climate during the LIA shows generally lower levels of variability in the western USA (Cook, 2004; Cook et al., 2007), though tree-ring reconstructions of summer temperatures in the Sawtooth and Salmon River Mountains indicate multidecadal periods of extreme cooling ca. 650, 610, 560, and after $350 \mathrm{cal}$ yr BP (Biondi et al., 1999). Nonetheless, substantial fire-related debris-flow activity occurred in the MFSR in both upper and lower basins 570-320 and 260-0 cal yr BP. A clear regional peak in fire activity in alluvial charcoal records is seen at about 550 cal yr BP, especially across drier, lower-elevation environments of the lower South Fork Payette River (Pierce et al., 2004), Wood Creek (Nelson and Pierce, 2010), and City of Rocks, Idaho (Weppner et al., 2013). The prominence of this peak is in part due to better preservation and exposure of young alluvial sediments, but it also corresponds to a period of relative warmth and drought ca. $550 \mathrm{cal}$ yr BP in tree-ring reconstructions (Biondi et al., 1999), and is preceded by a century-long period of colder and effectively wetter climate that likely allowed denser forest stands to develop. 
This is an author-produced, peer-reviewed version of this article. The final, definitive version of this document can be found online at The Holocene, published by SAGE. Copyright restrictions may apply. doi: 10.1177/0959683615571423

Episodic drought conditions in the early LIA are inferred from punctuated declines in pine from 600-500 cal yr BP in the Sawtooth Mountains (Whitlock et al., 2010), and tree-ring data also indicate relatively warm conditions ca. 450 cal yr BP (Biondi et al., 1999).

\section{Conclusions}

The long-term record of fire and erosion in the Middle Fork Salmon River basin demonstrates that fire has been a primary ecosystem process over Holocene timescales, including in its major role in driving erosional events. Firerelated deposits comprise about $66 \%$ of all alluvial fan deposits from upper tributary basins, suggesting that fire is the dominant agent of erosion and sedimentation in these more densely forested landscapes. In the lower MFSR watershed, fire-related deposits make up about 33\% of the total, indicating that fire is less important driver in erosion in this sparsely forested and rangeland environment, where debris flows can more readily be generated in the absence of fire (Meyer and Leidecker, 1999).

Fire severity, vegetation type, and climate conditions have influenced the type of erosional response recorded in alluvial deposits. The latest Pleistocene-early Holocene record of fire-related sedimentation is sparse, but large debris flows dating to this period suggest that fire was driving part of the geomorphic response to this major climatic transition. Relatively small fire-related sheetfloods were more common in the warm and dry middle Holocene, likely because low-severity fires were the dominant regime on sparsely vegetated hillslopes (e.g., Whitlock et al., 2004; Marlon et al., 2006).

With the onset of cooler and wetter climate conditions and denser forest stands during the last $4000 \mathrm{yr}$, fires have generally increased in severity, as indicated by the abundance of fire-related debris-flow deposits dating within this period. The development of closed lodgepole pine stands in high-elevation forests $\sim 2.5$ ka (Whitlock et al., 2010) also promoted high-severity stand-replacing fires. Intervals of greater fire-related debris-flow activity within the late Holocene correspond to warm and drought-prone periods such as the Medieval Climatic Anomaly; however, unlike in the nearby South Fork Payette River basin (Pierce et al., 2004), fire-related debris flows were common during the Little Ice Age. The generally cool and moist conditions of the Little Ice Age likely allowed dense stands of lodgepole pine to predominate in higher-elevation mesic forests, and stimulated greater grass and shrub growth in the xeric sagebrush steppe of the lower MFSR as well. In fuel-limited ecosystems such as the lower MFSR, increased fuel loads also heighten the probability of widespread severe fires. Overall, our findings indicate that climate and vegetation change have played a very strong role in fire activity and associated erosion and sedimentation over the diverse environments of the MFSR basin.

Modern fires have burned over $40 \%$ of the MFSR watershed, and a substantial fraction of that area burned at high severity. While for some areas in the western U.S.A., prior fire suppression has substantially increased the size and severity of recent fires, the location of the MFSR within a rugged, designated wilderness area has limited the influence of fire suppression and other land-use activities, as in other remote areas of the Northern Rocky Mountains (Westerling et al., 2006). The extent and severity of recent fires in the geomorphically sensitive Idaho Batholith region raise concerns over the ecological impacts of such "megafires" in a warming and increasingly droughtstricken landscape.

Current climate models predict increased summer temperatures in Idaho over the next century (Mote and Salathe, 2009), and central Idaho is predicted to be highly vulnerable to increased fire activity due to its extensive forested area, sensitivity to changes in water balance, and earlier timing of spring warming (Westerling et al., 2006). Ecosystems throughout central Idaho will likely continue to burn in severe fires that will drive small, steep basins to produce fire-related debris flows.

\section{Acknowledgements}

Funding for the project was provided by the National Science Foundation EPSCoR (Grant \#EPS-0814387) to Pierce and by the Geological Society of America (Grant \#014L101150) to Riley, Department of Geosciences, Boise State University. Field assistance was provided by Austin Hopkins and Nick Sutfin. Logistical assistance was provided by Patt Hass. The USDA Forest Service provided permitting assistance. We thank Lisa Ely and an anonymous reviewer for thoughtful and constructive reviews. 


\section{References}

Agee JK. (1996) Fire Ecology of Pacific Northwest Forests. Island Press.

Arno SF, Scott JH and Hartwell MG. (1995) Age-class structure of old-growth ponderosa pine douglas-fir stands and its relationship to fire history. Usda Forest Service Intermountain Research Station Research Paper: 125.

Baker WL. (2006) Fire and restoration of sagebrush ecosystems. Wildlife Society Bulletin 34: 177-185.

Ballenger JAM and Mabry JB. (2011) Temporal frequency distributions of alluvium in the American Southwest: taphonomic, paleohydraulic, and demographic implications. Journal of Archaeological Science 38: 13141325.

Balling Jr RC, Meyer GA and Wells SG. (1992) Climate change in Yellowstone National Park: is the droughtrelated risk of wildfires increasing? Climatic Change 22: 35-45.

Barrett SW. (1988) Fire suppression's effects on forest succession within a central Idaho wilderness. Western Journal of Applied Forestry 3: 76-80.

Bartlein PJ, Anderson KH, Anderson P, et al. (1998) Paleoclimate simulations for North America over the past 21,000 years features of the simulated climate and comparisons with paleoenvironmental data. Quaternary Science Reviews 17: 549-585.

Biondi F, Perkins D, Cayan D, et al. (1999) July temperature during the second millennium reconstructed from Idaho tree rings. Geophysical Research Letters 26: 1445-1448.

Bowman DMJS, Balch JK, Artaxo P, et al. (2009) Fire in the Earth system. Science 324: 481-484.

Brown PM, Kaufmann MR and Shepperd WD. (1999) Long-term, landscape patterns of past fire events in a montane ponderosa pine forest of central Colorado. Landscape Ecology 14: 513-532.

Brunelle A, Whitlock C, Bartlein P, et al. (2005) Holocene fire and vegetation along environmental gradients in the Northern Rocky Mountains. Quaternary Science Reviews 24: 2281-2300.

Bukowski BE and Baker WL. (2013) Historical fire regimes, reconstructed from land-survey data, led to complexity and fluctuation in sagebrush landscapes. Ecological applications 23: 546-564.

Cannon S, Gartner J, Parrett C, et al. (2003) Wildfire-related debris flow generation through episodic progressive sediment bulking processes, western USA. Debris-Flow Hazards Mitigation: Mechanics, Prediction, and Assessment, Proceedings of the Third International Conference on Debris-flow Hazards Mitigation, Millpress, Rotterdam. 71-82.

Cannon SH. (2001) Debris-flow generation from recently burned watersheds. Environmental \& Engineering Geoscience 7: 321-341.

Cannon SH and Gartner JE. (2005) Wildfire-related debris flow from a hazards perspective. Debris-flow Hazards and Related Phenomena. Springer, 363-385.

Cannon SH, Gartner JE, Rupert MG, et al. (2010) Predicting the probability and volume of postwildfire debris flows in the intermountain western United States. Geological Society of America Bulletin 122: 127-144.

Carrara PE. (1989) Late Quaternary glacial and vegetative history of the Glacier National Park region, Montana. US Geological Survey Bulletin 1902: 1-64.

Cochrane MA, United Nations Environment Programme. Division of Early W, Assessment, et al. (2002) Spreading like wildfire : tropical forest fires in Latin America and the Caribbean : prevention, assessment and early warning, Mexico, D.F.: DEWA.

Cook E. (2004) North American Summer PDSI Reconstructions.

Cook ER, Seager R, Cane MA, et al. (2007) North American drought: Reconstructions, causes, and consequences. Earth-Science Reviews 81: 93-134.

Cook ER, Woodhouse CA, Eakin CM, et al. (2004) Long-term aridity changes in the western United States. Science 306: 1015-1018.

Davis LG, Muehlenbachs K, Schweger CE, et al. (2002) Differential response of vegetation to postglacial climate in the Lower Salmon River Canyon, Idaho. Palaeogeography, Palaeoclimatology, Palaeoecology 185: 339354.

Despain DG. (1990) Yellowstone vegetation: consequences of environment and history in a natural setting. Boulder, Colorado: Roberts Rinehart Publishers, Inc.

Esper J, Cook ER and Schweingruber FH. (2002) Low-frequency signals in long tree-ring chronologies for reconstructing past temperature variability. Science 295: 2250-2253.

Forsyth GG and Van Wilgen BW. (2008) The recent fire history of the Table Mountain National Park and implications for fire management. Koedoe 50: 3-9. 
This is an author-produced, peer-reviewed version of this article. The final, definitive version of this document can be found online at The Holocene, published by SAGE. Copyright restrictions may apply. doi: 10.1177/0959683615571423

Frueh WT and Lancaster ST. (2014) Correction of deposit ages for inherited ages of charcoal: implications for sediment dynamics inferred from random sampling of deposits on headwater valley floors. Quaternary Science Reviews 88: 110-124.

Gavin DG. (2001) Estimation of inbuilt age in radiocarbon ages of soil charcoal for fire history studies. Radiocarbon 43: 27-44.

Goode JR, Luce CH and Buffington JM. (2012) Enhanced sediment delivery in a changing climate in semi-arid mountain basins: Implications for water resource management and aquatic habitat in the northern Rocky Mountains. Geomorphology 139: 1-15.

Grove JM. (1988) The Little Ice Age. New York: Methuen.

Heyerdahl EK, Morgan P and Riser JP. (2008) Multi-season climate synchronized historical fires in dry forests (1650-1900), northern Rockies, USA. Ecology 89: 705-716.

Hostetler SW, Bartlein PJ and Holman JO. (2006) Atlas of climatic controls of wildfire in the western United States. Scientific Investigations Report. - ed., iv, 69 p.

IPPC. (2007) Climate Change 2007: The Physical Science Basis

In: Change WGIttFARotIPoC (ed). Cambridge University Press.

Iverson RM. (1997) The physics of debris flows. Reviews of Geophysics 35: 245-296.

Key CH and Benson NC. (1999) Measuring and remote sensing of burn severity: the CBI and NBR. In: Neuenschwander LF and Ryan KC (eds) Proceedings Joint Fire Science Conference and Workshop. Boise, ID: University of Idaho and International Association of Wildland Fire, 284 pp.

Lavee H, Kutiel P, Segev M, et al. (1995) Effect of surface roughness on runoff and erosion in a Mediterranean ecosystem: the role of fire. Geomorphology 11: 227-234.

Lohman DJ, Bickford D and Sodhi NS. (2007) The burning issue. Science 316: 376.

Luckman BH. (2000) The Little Ice Age in the Canadian Rockies. Geomorphology 32: 357-394.

Mann ME, Zhang Z, Rutherford S, et al. (2009) Global signatures and dynamical origins of the Little Ice Age and Medieval Climate Anomaly. Science 326: 1256-1260.

Marlon J, Bartlein PJ and Whitlock C. (2006) Fire-fuel-climate linkages in the northwestern USA during the Holocene. Holocene 16: 1059-1071.

Marlon JR, Bartlein PJ, Walsh MK, et al. (2009) Wildfire responses to abrupt climate change in North America. Proceedings of the National Academy of Sciences of the United States of America 106: 2519-2524.

Meyer G and Leidecker M. (1999) Fluvial terraces along the Middle Fork Salmon River, Idaho, and their relation to glaciation, landslide dams, and incision rates: a preliminary analyses and river mile guide. Guidebook to the Geology of Eastern Idaho. Pocatello, ID: Museum of Natural History, 219-235.

Meyer GA. (2004) Yellowstone fires and the physical landscape. In: Wallace LL (ed) After the fires: the ecology of change in Yellowstone National Park. New Haven: Yale University Press, 29-51.

Meyer GA and Pierce JL. (2003) Climatic controls on fire-induced sediment pulses in Yellowstone National Park and central Idaho: a long-term perspective. Forest Ecology and Management 178: 89-104.

Meyer GA, Pierce JL, Wood SH, et al. (2001) Fires, storms, and erosional events in the Idaho batholith. Hydrological Processes 15: 3025-3038.

Meyer GA and Wells SG. (1997) Fire-related sedimentation events on alluvial fans, Yellowstone National Park, USA. Journal of Sedimentary Research 67: 776-791.

Meyer GA, Wells SG and Jull AJT. (1995) Fire and alluvial chronology in Yellowstone National Park: Climatic and intrinsic controls on Holocene geomorphic processes. Geological Society of America Bulletin 107: 12111230.

Monitoring Trends in Burn Severity. (2010) Monitoring Trends in Burn Severity Data Access. Available at: http://mtbs.gov/dataquery/individualfiredata.html

Morgan P, Heyerdahl EK and Gibson CE. (2008) Multi-season climate synchronized forest fires throughout the 20th century, northern Rockies, USA. Ecology 89: 717-728.

Mote PW and Salathe EP. (2009) Future climate in the Pacific Northwest (in press). Washington Climate Change Impacts Assessment: Evaluating Washington's future in a changing climate.

Nelson NA and Pierce J. (2010) Late-Holocene relationships among fire, climate and vegetation in a forestsagebrush ecotone of southwestern Idaho, USA. Holocene 20: 1179-1194.

Page SE, Siegert F, Rieley JO, et al. (2002) The amount of carbon released from peat and forest fires in Indonesia during 1997. Nature 420: 61-65.

Parise M and Cannon S. (2012) Wildfire impacts on the processes that generate debris flows in burned watersheds. Natural Hazards 61: 217-227. 
Peek JM. (2000) Shrub-Steppe Vegetation Trend, Middle Fork Salmon River, Idaho. Wilderness Science in a Time of Change Conference: Wilderness as a place for scientific inquiry. US Department of Agriculture, Forest Service, Rocky Mountain Research Station, 117.

Pierce JL and Meyer GA. (2008) Long-term fire history from alluvial fan sediments: the role of drought and climate variability, and implications for management of Rocky Mountain forests. International Journal of Wildland Fire 17: 84-95.

Pierce JL, Meyer GA and Jull AJT. (2004) Fire-induced erosion and millennialscale climate change in northern ponderosa pine forests. Nature 432: 87-90.

Pierson TC. (2005) Hyperconcentrated flow-transitional process between water flow and debris flow. Debris-flow Hazards and Related Phenomena. Springer, 159-202.

Pollack HN, Huang S and Shen P. (1998) Climate change record in subsurface temperatures: a global perspective. Science 282: 279-281.

Power MJ, Marlon J, Ortiz N, et al. (2008) Changes in fire regimes since the Last Glacial Maximum: an assessment based on a global synthesis and analysis of charcoal data. Climate Dynamics 30: 887-907.

Reimer PJ, Baillie MGL, Bard E, et al. (2004) IntCal04 terrestrial radiocarbon age calibration, 0-26 cal kyr BP. Radiocarbon 46: 1029-1058.

Riley KE. (2012) A 14,000-year Record of Wildfire and Alluvial Fan Deposition Reveals Relationships Among Fire, Climate, Vegetation, and Sediment Yields in the Middle Fork Salmon River, Idaho.

Schmidt KM. (2001) The variability of root cohesion as an influence on shallow landslide susceptibility in the Oregon Coast Range. Canadian Geotechnical Journal 38: 995-1024.

Schoennagel T, Veblen TT and Romme WH. (2004) The Interaction of Fire, Fuels, and Climate across Rocky Mountain Forests. BioScience 54: 661-676.

Shakesby RA and Doerr SH. (2006) Wildfire as a hydrological and geomorphological agent. Earth-Science Reviews 74: 269-307.

Shinneman DJ and Baker WL. (1997) Nonequilibrium dynamics between catastrophic disturbances and old-growth forests in ponderosa pine landscapes of the Black Hills. Conservation Biology 11: 1276-1288.

Shuman B, Henderson AK, Colman SM, et al. (2009) Holocene lake-level trends in the Rocky Mountains, USA. Quaternary Science Reviews 28: 1861-1879.

Steele R, Pfister RD, Ryker RA, et al. (1981) Forest Habitat Tyes of Central Idaho. In: Service F (ed). Intermountain Forest and Range Experiment Station.

Stewart G and Hull AC. (1949) Cheatgrass (Bromus Tectorum L.)--An Ecologic Intruder in Southern Idaho. Ecology 30: 58-74.

Stine S. (1994) Extreme and Persistent Drought in California and Patagonia During Medieval Time Nature 369: 546-549.

Surovell TA, Finley JB, Smith GM, et al. (2009) Correcting temporal frequency distributions for taphonomic bias. Journal of Archaeological Science 36: 1715-1724.

Svenson LO. (2010) Fire and Climate in a Lodgepole Forest of Central Idaho: Annual, Decadal, Centennial, and Millennial Perspectives. Boise State University, ID.

Swetnam TW. (1993) Fire history and climate-change in giant sequoia groves. Science 262: 885-889.

Telford RJ, Heegaard E and Birks HJB. (2004) The intercept is a poor estimate of a calibrated radiocarbon age. The Holocene 14: 296-298.

Tennant CJ. (2010) The Influence of Precipitation Phase on Hydrograph Form. Idaho State University.

Wells SG and Harvey AM. (1987) Sedimentologic and geomorphic variations in storm-generated alluvial fans, Howgill Fells, northwest England. Geological Society of America Bulletin 98: 182-198.

Weppner, K., Pierce, J.L., Betancourt, J.L., 2013, Holocene Fire Occurrence and Alluvial Responses at the Leading Edge of Pinyon-Juniper Migration in the Northern Great Basin. Quaternary Research 80, 143-157.

Westerling AL, Gershunov A, Brown TJ, et al. (2003) Climate and wildfire in the western United States. Bulletin of the American. Meteorological Society 84: 595-604.

Westerling AL, Hidalgo HG, Cayan DR, et al. (2006) Warming and earlier spring increase western US forest wildfire activity. Science 313: 940-943.

Whitlock, C, Briles, CE, Fernandez, MC., and Gage, J. (2011). Holocene vegetation, fire and climate history of the Sawtooth Range, central Idaho, USA.Quaternary Research, 75(1): 114-124.

Whitlock C, Dean W, Rosenbaum J, et al. (2008) A 2650-year-long record of environmental change from northern Yellowstone National Park based on a comparison of multiple proxy data. Quaternary International 188: 126-138. 
This is an author-produced, peer-reviewed version of this article. The final, definitive version of this document can be found online at The Holocene, published by SAGE. Copyright restrictions may apply. doi: 10.1177/0959683615571423

Whitlock C, Shafer SL and Marlon J. (2003) The role of climate and vegetation change in shaping past and future fire regimes in the northwestern US and the implications for ecosystem management. Forest Ecology and Management 178: 5-21.

Whitlock C, Skinner CN, Bartlein PJ, et al. (2004) Comparison of charcoal and tree-ring records of recent fires in the eastern Klamath Mountains, California, USA. Canadian Journal of Forest Research 34: 2110-2121.

Wondzell SM and King JG. (2003) Postfire erosional processes in the Pacific Northwest and Rocky Mountain regions. Forest Ecology and Management 178: 75-87.

Woodhouse CA, Meko DM, MacDonald GM, et al. (2010) A 1,200-year perspective of 21st century drought in southwestern North America. Proceedings of the National Academy of Sciences 107: 21283-21288. 


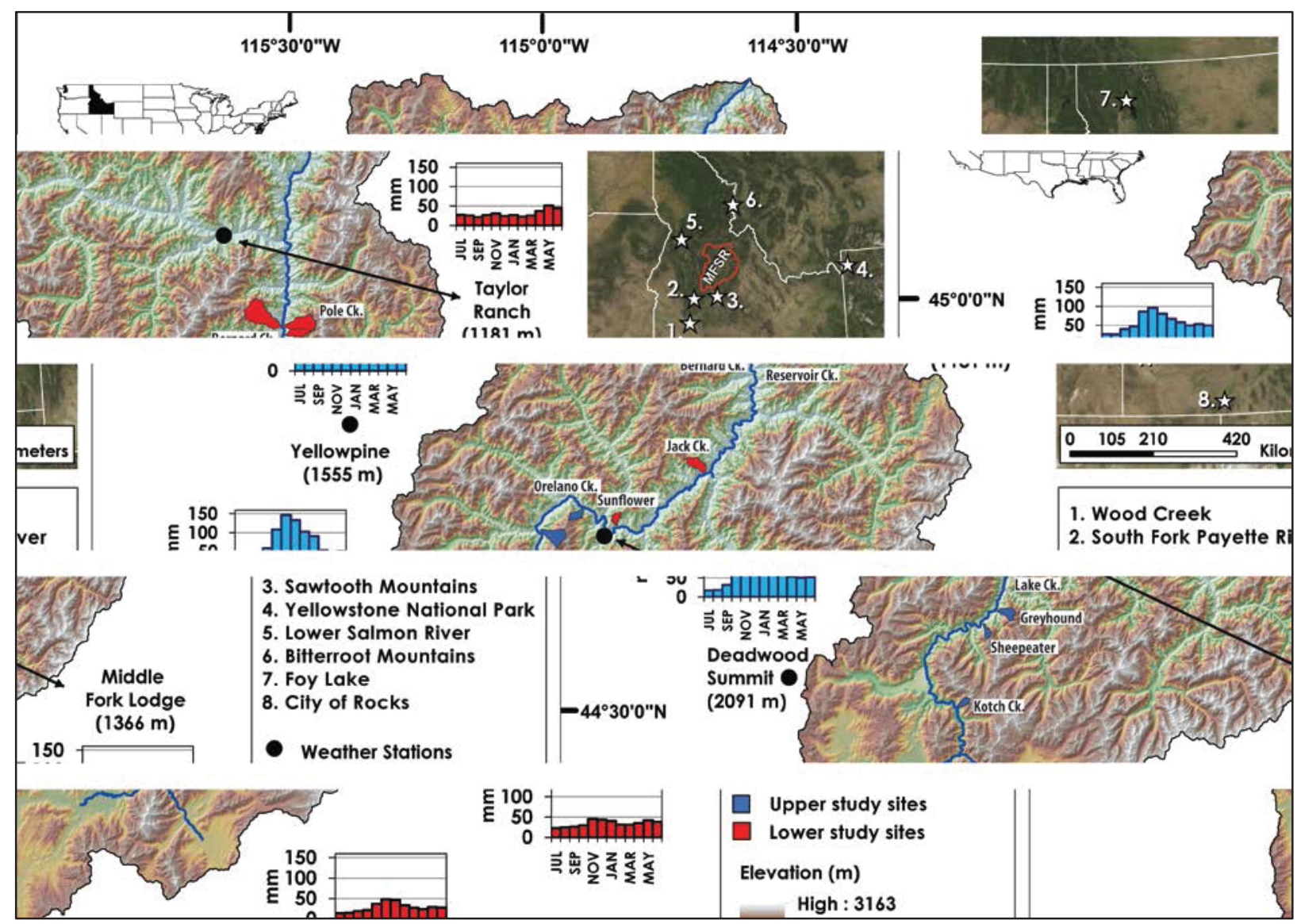

Figure 1: Map of the Middle Fork Salmon River (MFSR) watershed. Polygons show five relatively low-elevation, dry, less-forested sub-basins (red), and five higher, wetter, and more-forested sub-basins (blue) selected as study sites. Each sub-basin contains a recently incised alluvial fan at the MFSR confluence. Bar graphs show average monthly precipitation in millimeters at the nearest five SNOTEL and COOP weather stations; station elevations are in parentheses; red bars indicate lower elevation and blue bars higher elevation stations. Numbered white stars on the regional map (upper right) represent the locations of climate proxy data discussed in this study. 
This is an author-produced, peer-reviewed version of this article. The final, definitive version of this document can be found online at The Holocene, published by SAGE. Copyright restrictions may apply. doi: 10.1177/0959683615571423

Table 1: Summary of ${ }^{14} \mathrm{C}$-dated deposits ordered by sub-basin, profile, and then depth.

\begin{tabular}{|c|c|c|c|c|c|c|c|c|c|c|}
\hline$\underset{\#}{\text { Sample }}$ & $\begin{array}{l}\text { Lab } \\
\text { Code }\end{array}$ & $\begin{array}{c}\text { Sample Code } \\
\text { (basin-profile- } \\
\text { sample) }\end{array}$ & $\begin{array}{c}\text { Basin/ } \\
\text { Classification }\end{array}$ & $\begin{array}{l}\text { Interpreted } \\
\text { Depositional } \\
\text { Process }\end{array}$ & $\begin{array}{c}\text { Fire } \\
\text { Related } \S\end{array}$ & $\begin{array}{l}\text { Depth } \\
\text { (cm) }\end{array}$ & $\begin{array}{l}\text { Thickness } \\
\text { (cm) }\end{array}$ & $\begin{array}{l}\% \\
\text { Total } \\
\text { Depth }\end{array}$ & $\begin{array}{l}{ }^{14} \mathrm{C} \text { age } \\
( \pm 1 \text { sigma })\end{array}$ & $\begin{array}{c}\text { Calibrated Weighted } \\
\text { Mean } \\
\text { ( } 2 \text { sigma) }\end{array}$ \\
\hline 1 & 153900 & KC-02-01 & Kotch/Upper & Debris flow & $\mathrm{FR}$ & $30-45$ & 15 & $9 \%$ & $335 \pm 60$ & $390 \pm 80$ \\
\hline 2 ** & 153901 & KC-02-04 & Kotch/Upper & $\begin{array}{l}\text { Burn surface below } \\
\text { sheetflood }\end{array}$ & FR & $58-60$ & 14 & $9 \%$ & $1070 \pm 60$ & $980 \frac{+70}{-60}$ \\
\hline $3 *$ & 153902 & KC-02-05 & Kotch/Upper & Debris Flow & $\mathrm{FR}$ & $60-86$ & 26 & $16 \%$ & $1190 \pm 60$ & $1120 \pm 60$ \\
\hline 4 *夫 & 153903 & KC-02-06 & Kotch/Upper & Debris flow & moderate & $95-135$ & 40 & $25 \%$ & $2170 \pm 60$ & $2210 \frac{+130}{-60}$ \\
\hline 5 ** & 149564 & SHS-03-03 & Sheepeater/Upper & Debris flow & scarce & $131-150$ & 19 & $13 \%$ & $3481 \pm 68$ & $3750 \frac{+170}{-180}$ \\
\hline 6 * & AA88192 & SHS-04-04 & Sheepeater/Upper & Inset debris flow & $\mathrm{FR}$ & $390-415$ & 25 & 0.05 & modern & modern \\
\hline $7^{*}$ & AA88193 & SHS-06-03 & Sheepeater/Upper & Debris flow & $\mathrm{FR}$ & $57-110$ & 53 & $48 \%$ & $675 \pm 35$ & $620 \frac{+60}{-80}$ \\
\hline $8^{\star \star} \dagger$ & 149557 & SHS-07-03A & Sheepeater/Upper & Burn surface & $\mathrm{FR}$ & $147-148$ & 57 & $32 \%$ & $900 \pm 35$ & $830 \frac{+80}{-90}$ \\
\hline $9^{* \star} \dagger$ & 149571 & SHS-07-03B & Sheepeater/Upper & Burn surface & $\mathrm{FR}$ & $147-148$ & 57 & $32 \%$ & $870 \pm 35$ & $790 \frac{+110}{-100}$ \\
\hline 10 ** & 153914 & SHS-08-02B & Sheepeater/Upper & Debris flow & $\mathrm{FR}$ & $210-270$ & 60 & $14 \%$ & $4520 \pm 90$ & $5170 \frac{+150}{-130}$ \\
\hline $11^{\text {** }}$ & 149547 & SHS-08-05 & Sheepeater/Upper & Burn surface & $\mathrm{FR}$ & $330-350$ & 30 & $7 \%$ & $9960 \pm 45$ & $11410 \frac{+200}{-160}$ \\
\hline 12 ** & 149561 & GHC-01-05 & Greyhound/Upper & $\begin{array}{l}\text { Burn surface w/ } \\
\text { Sheetflood }\end{array}$ & $\mathrm{FR}$ & $350-359$ & 14 & $4 \%$ & $1637 \pm 36$ & $1520 \frac{+90}{-110}$ \\
\hline $13^{\star \star}$ & 149559 & GHC-02-03 & Greyhound/Upper & Overbank & $\mathrm{FR}$ & $157-161$ & 4 & $2 \%$ & $1462 \pm 36$ & $1350 \pm 50$ \\
\hline $144^{\star \star} \dagger$ & 149569 & GHC-02-05A & Greyhound/Upper & $\begin{array}{l}\text { Burn Surface below } \\
\text { overbank }\end{array}$ & $\mathrm{FR}$ & 163-165 & 4 & $2 \%$ & $1525 \pm 35$ & $1420 \frac{+100}{-80}$ \\
\hline $15 * \dagger$ & 149556 & GHC-02-05B & Greyhound/Upper & $\begin{array}{l}\text { Burn surface below } \\
\text { overbank }\end{array}$ & FR & $163-165$ & 4 & $2 \%$ & $1485 \pm 35$ & $1370 \frac{+140}{-70}$ \\
\hline 16 * & AA88196 & LC-01-03 & Lake/Upper & Overbank & $\mathrm{FR}$ & $225-226$ & 2 & $<1 \%$ & $385 \pm 34$ & $430 \frac{+80}{-110}$ \\
\hline $17^{\star \star} \dagger$ & 153904 & LC01-05A & Lake/Upper & $\begin{array}{l}\text { Burn surface below } \\
\text { sheetflood }\end{array}$ & $\mathrm{FR}$ & $268-277$ & 37 & $7 \%$ & $1880 \pm 60$ & $1820 \frac{+70}{-90}$ \\
\hline $18^{* \star} \dagger$ & 153897 & LC01-05B & Lake/Upper & $\begin{array}{l}\text { Burn surface below } \\
\text { sheetflood }\end{array}$ & $\mathrm{FR}$ & $266-277$ & 37 & $7 \%$ & $1955 \pm 60$ & $1910 \pm 80$ \\
\hline $199^{\star \star} \dagger$ & 149551 & LC-01-06A & Lake/Upper & Debris flow & $\mathrm{FR}$ & $277-300$ & 23 & $4 \%$ & $2660 \pm 30$ & $2780 \frac{+70}{-30}$ \\
\hline $20 * \dagger$ & AA88201 & LC-01-06B & Lake/Upper & Debris flow & FR & $277-300$ & 23 & $4 \%$ & $3510 \pm 45$ & $3780 \frac{+120}{-140}$ \\
\hline $211^{\star \star} \dagger$ & 153905 & LC-01-07A & Lake/Upper & $\begin{array}{l}\text { Burn surface below } \\
\text { debris flow }\end{array}$ & $\mathrm{FR}$ & $320-326$ & 26 & $5 \%$ & $6325 \pm 90$ & $7250 \frac{+80}{-90}$ \\
\hline $222^{\star \star} \dagger$ & 153898 & LC01-07B & Lake/Upper & $\begin{array}{l}\text { Burn surface below } \\
\text { debris flow }\end{array}$ & $\mathrm{FR}$ & $320-326$ & 26 & $5 \%$ & $6280 \pm 90$ & $7200 \frac{+110}{-140}$ \\
\hline $23^{\star \star} \dagger$ & 149566 & LC-01-08A & Lake/Upper & Burn surface & FR & $335-340$ & 5 & $1 \%$ & $5785 \pm 35$ & $6580 \frac{+80}{-90}$ \\
\hline $24 * \dagger$ & AA88197 & LC-01-08B & Lake/Upper & Burn surface & $\mathrm{FR}$ & $335-340$ & 5 & $1 \%$ & $5850 \pm 30$ & $6670 \frac{+70}{-100}$ \\
\hline 25 ** & 149552 & LC-01-10 & Lake/Upper & $\begin{array}{l}\text { Burn surface below } \\
\text { overbank }\end{array}$ & $\mathrm{FR}$ & $355-367$ & 19 & $4 \%$ & $7347 \pm 47$ & $8150 \frac{+160}{-130}$ \\
\hline $26 * \star$ & 149570 & LC-01B-11A & Lake/Upper & Debris flow & Scarce & $373-420$ & 47 & $9 \%$ & $8040 \pm 30$ & $8920 \frac{+100}{-140}$ \\
\hline $27^{\star \star} \dagger$ & 149549 & LC-01B-11B & Lake/Upper & Debris flow & Scarce & $373-420$ & 47 & $9 \%$ & $8780 \pm 35$ & $9800 \frac{+320}{-170}$ \\
\hline 28 * & AA88198 & LC-01-13 & Lake/Upper & $\begin{array}{l}\text { Charcoal rich sands } \\
\text { (inset flood) }\end{array}$ & FR & $425-530$ & unknown & NA & modern & modern \\
\hline 29 * & AA88199 & LC-02-05 & Lake/Upper & Debris flow & FR & $350-470$ & 140 & $27 \%$ & $380 \pm 36$ & $420 \frac{+90}{-110}$ \\
\hline $30 * * t$ & 149568 & OC-04B-02B & Orelano/Upper & $\begin{array}{l}\text { Burn surface below } \\
\text { debris flow }\end{array}$ & FR & $25-26$ & 11 & $5 \%$ & modern & modern \\
\hline $31 * \dagger$ & 149560 & OC-04B-02A & Orelano/Upper & $\begin{array}{l}\text { Burn surface below } \\
\text { debris flow }\end{array}$ & FR & $25-26$ & 11 & $5 \%$ & $90 \pm 30$ & $130 \frac{+140}{-130}$ \\
\hline 32 * & AA88195 & OC-04-01 & Orelano/Upper & Sheetflood & FR & $150-151$ & 10 & $2 \%$ & $1195 \pm 41$ & $1120 \frac{+80}{-130}$ \\
\hline 33 ** & 149575 & OC-04-04 & Orelano/Upper & Debris flow & FR & $200-201$ & 120 & $36 \%$ & $4693 \pm 48$ & $5430 \frac{+100}{-110}$ \\
\hline 34 * & AA88203 & OC-03-03 & Orelano/Upper & $\begin{array}{l}\text { Burn surface below } \\
\text { debris flow }\end{array}$ & FR & $235-255$ & 75 & $15 \%$ & $955 \pm 35$ & $860 \pm 70$ \\
\hline 35 ** & 149567 & OC-03-06 & Orelano/Upper & $\begin{array}{l}\text { Burn surface with soil } \\
\text { below }\end{array}$ & FR & $415-495$ & 80 & $16 \%$ & $875 \pm 25$ & $790 \frac{+110}{-60}$ \\
\hline
\end{tabular}


This is an author-produced, peer-reviewed version of this article. The final, definitive version of this document can be found online at The Holocene, published by SAGE. Copyright restrictions may apply. doi: 10.1177/0959683615571423

Table 1: (continued)

\begin{tabular}{|c|c|c|c|c|c|c|c|c|c|c|}
\hline $\begin{array}{l}\text { Sample } \\
\quad \#\end{array}$ & $\begin{array}{l}\text { Lab } \\
\text { Code }\end{array}$ & $\begin{array}{c}\text { Sample Code } \\
\text { (basin-profile- } \\
\text { sample) }\end{array}$ & $\begin{array}{c}\text { Basin/ } \\
\text { Classification }\end{array}$ & $\begin{array}{c}\text { Interpreted } \\
\text { Depositional Process }\end{array}$ & $\begin{array}{c}\text { Fire } \\
\text { Related } \\
\S \\
\end{array}$ & $\begin{array}{l}\text { Depth } \\
\text { (cm) }\end{array}$ & $\begin{array}{l}\text { Thickness } \\
\text { (cm) }\end{array}$ & $\begin{array}{c}\% \\
\text { Total } \\
\text { Depth }\end{array}$ & $\begin{array}{c}{ }^{14} \mathrm{C} \text { age } \\
( \pm 1 \text { sigma) }\end{array}$ & $\begin{array}{c}\text { Calibrated Weighted } \\
\text { Mean } a \\
( \pm 2 \text { sigma })\end{array}$ \\
\hline $36^{* *}$ & 149546 & SC-01-02 & Sunflower/Lower & $\begin{array}{l}\text { Burn surface below } \\
\text { sheetflood }\end{array}$ & FR & $312-316$ & $10-197$ & $2-39 \%$ & $5110 \pm 40$ & $5840 \pm 90$ \\
\hline $37^{*}$ & AA88204 & SC-01-04 & Sunflower/Lower & Sheetflood & FR & $405-406$ & 21 & $4 \%$ & $5650 \pm 35$ & $6430 \frac{+70}{-110}$ \\
\hline 38 ** & 149562 & HR-01-06 & Hood/Lower & Debris flow & FR & $111-147$ & 36 & $24 \%$ & $7720 \pm 50$ & $8500 \frac{+90}{-80}$ \\
\hline 39 ** & 149547 & JC-01-02 & Jack/Lower & Debris flow & Scarce & $195-373$ & 178 & $48 \%$ & $11730 \pm 130$ & $13580 \pm 260$ \\
\hline 40 * & AA88205 & RC-03-02 & Reservoir/Lower & $\begin{array}{l}\text { Burn surface below } \\
\text { debris flow }\end{array}$ & FR & $18-19$ & 27 & $8 \%$ & $243 \pm 38$ & $250 \frac{+180}{-250}$ \\
\hline $41^{* \star}$ & 149576 & RC-03-03 & Reservoir/Lower & Sheetflood & $\mathrm{FR}$ & $62-67$ & $5-27$ & $2-8 \%$ & $2095 \pm 30$ & $2070 \frac{+80}{-70}$ \\
\hline $42 *$ & AA88191 & RC-03-08 & Reservoir/Lower & Debris flow & Scarce & $89-171$ & 82 & $25 \%$ & $2770 \pm 45$ & $2870 \pm 100$ \\
\hline $43^{* *}$ & 149545 & RC-03-10 & Reservoir/Lower & Sheetflood & FR & $236-241$ & 3 & $1 \%$ & $5005 \pm 30$ & $5750 \frac{+140}{-100}$ \\
\hline $44^{* *}$ & 149548 & RC-03-18 & Reservoir/Lower & Sheetflood & $\mathrm{FR}$ & $324-326$ & $2-121$ & $1-36 \%$ & $5585 \pm 50$ & $6370 \frac{+90}{-80}$ \\
\hline $45^{\star *}$ & 149565 & RC-03-19 & Reservoir/Lower & Sheetflood & FR & $326-332$ & $14-90$ & $4-26 \%$ & $5689 \pm 64$ & $6480 \frac{+150}{-170}$ \\
\hline $46^{*}$ & AA88202 & BC-01-01 & Bernard/Lower & $\begin{array}{l}\text { Burn surface below } \\
\text { debris flow }\end{array}$ & FR & $21-22$ & 22 & $8 \%$ & $147 \pm 38$ & $150 \frac{+140}{-150}$ \\
\hline $47^{* \star}$ & 149558 & BC-01-03 & Bernard/Lower & Burn surface & $\mathrm{FR}$ & $71-76$ & 5 & $2 \%$ & $95 \pm 30$ & $130 \frac{+160}{-130}$ \\
\hline $48^{* \star} \dagger$ & 149572 & BC-01-06B & Bernard/Lower & Debris flow & Scarce & $216-251$ & 35 & $14 \%$ & $520 \pm 35$ & $550 \frac{+80}{-40}$ \\
\hline $59^{* \star} \dagger$ & 149574 & BC-01-06A & Bernard/Lower & Reworked charcoal & FR & $216-251$ & 35 & $14 \%$ & $925 \pm 35$ & $850 \frac{+80}{-100}$ \\
\hline 50 * & AA88210 & BC-02-04 & Bernard/Lower & Burn surface & FR & $130-132$ & 2 & $2 \%$ & $1008 \pm 40$ & $910 \frac{+10}{-120}$ \\
\hline $51^{\star *}$ & 153909 & BC-05-03 & Bernard/Lower & Debris flow & Scarce & $28-50$ & 22 & $10 \%$ & $365 \pm 60$ & $410 \frac{+90}{-100}$ \\
\hline 52 ** & 153910 & BC-05-04 & Bernard/Lower & Debris flow & FR & $50-73$ & 23 & $11 \%$ & $1830 \pm 70$ & $1770 \frac{+100}{-70}$ \\
\hline $53^{\star *}$ & 153911 & BC-05-08 & Bernard/Lower & Sheetflood & FR & $121-133$ & $12-55$ & $5-25 \%$ & $2735 \pm 90$ & $2830 \frac{+90}{-80}$ \\
\hline 54 ** & 153912 & BC-05-09 & Bernard/Lower & Overbank & FR & $154-196$ & 42 & $19 \%$ & $2975 \pm 90$ & $3160 \frac{+110}{-160}$ \\
\hline $55^{\star \star}$ & 153913 & BC-05-10 & Bernard/Lower & Debris flow & FR & $196-219$ & 23 & $11 \%$ & $3405 \pm 80$ & $3660 \frac{+170}{-100}$ \\
\hline $57^{*}$ & AA88206 & HR-01-01 & Pole/Lower & $\begin{array}{l}\text { Burn surface below } \\
\text { debris flow }\end{array}$ & FR & $66-67$ & 67 & $19 \%$ & $419 \pm 82$ & $440 \frac{+120}{-140}$ \\
\hline $58 *$ & AA88207 & HR-01-02 & Pole/Lower & Sheetflood & $\mathrm{FR}$ & $270-296$ & 26 & $7 \%$ & $135 \pm 39$ & $140 \pm 140$ \\
\hline $59^{* \star} \dagger$ & 149550 & PC-08-01A & Pole/Lower & $\begin{array}{l}\text { Sheetflood within } \\
\text { debris flow }\end{array}$ & Scarce & $162-164$ & 2 & $1 \%$ & $1710 \pm 30$ & $1620 \frac{+80}{-70}$ \\
\hline $60 * \dagger$ & AA88194 & PC-08-01B & Pole/Lower & $\begin{array}{l}\text { Sheetflood within } \\
\text { debris flow }\end{array}$ & Scarce & $162-164$ & 224 & $79 \%$ & $1620 \pm 30$ & $1500 \frac{+100}{-80}$ \\
\hline $61^{* \star} \dagger$ & 149555 & PC-08-03A & Pole/Lower & $\begin{array}{l}\text { Burn surface below } \\
\text { debris flow }\end{array}$ & FR & $269-270$ & 31 & $11 \%$ & $2100 \pm 30$ & $2070 \frac{+70}{-80}$ \\
\hline $62^{\star \star} \dagger$ & 149563 & PC-08-03B & Pole/Lower & $\begin{array}{l}\text { Burn surface below } \\
\text { debris flow }\end{array}$ & FR & $269-270$ & 31 & $11 \%$ & $2230 \pm 35$ & $2240 \frac{+100}{-90}$ \\
\hline $56{ }^{*}$ & AA88208 & PC-02-06 & Pole/Lower & Sheetflood & FR & $580-590$ & 10 & 0.017 & modern & modern \\
\hline $63^{*}$ & AA88209 & NNC -01-01 & No name/Lower & Debris flow & FR & $163-167$ & 158 & 0.88 & modern & modern \\
\hline $64^{*}$ & AA88200 & NNC-01-02 & No name/Lower & Overbank & FR & $167-179$ & 12 & $7 \%$ & $1060 \pm 240$ & $410 \pm 1000$ \\
\hline
\end{tabular}

* Lab codes with AA are from NSF-AMS Facility at the University of Arizona

** Charcoal processed at AMS Facility at Lawrence Livermore National Laboratory

† Replicate sample (two samples from one discrete bed were dated)

$\S$ FR means the deposit was interpreted as fire-related (containing abundant charcoal and/or above burn surface). Scarce charcoal abundance was

interpreted as a non-fire-related deposit.

a Calibrated weighted mean ages were used to report a robust and stable age estimate (Telford et al., 2004). 


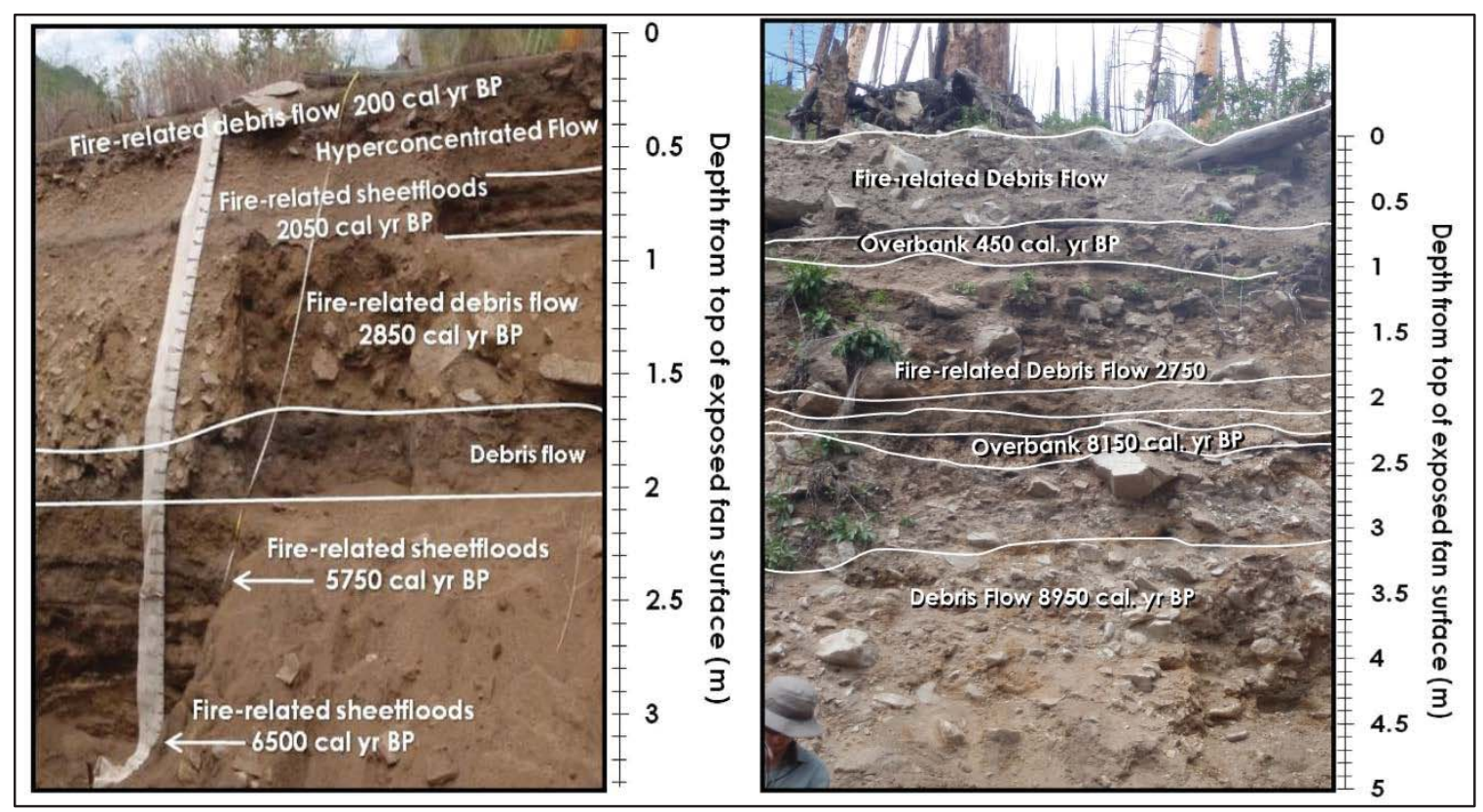

Figure 2: Photographs, deposit interpretation, and radiocarbon dates in calibrated calendar years before present of two stratigraphic profiles in incised alluvial fans of MFSR tributary basins: (left) Reservoir Creek, a lower-elevation sub-basin, and (right) Lake Creek, a more densely forested, higher-elevation sub-basin. 


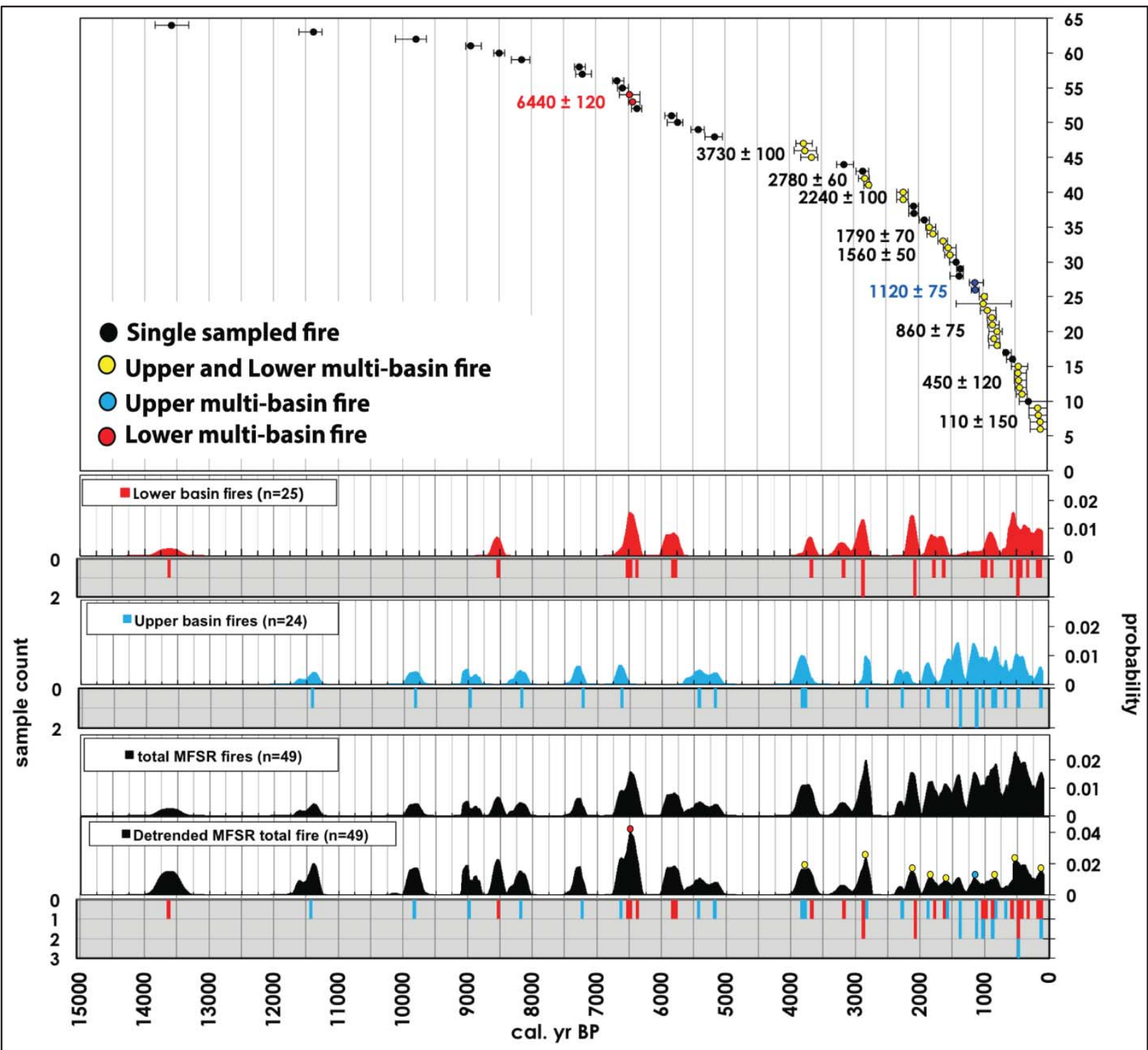

Figure 3: Top graph shows all calibrated ${ }^{14} \mathrm{C}$ dates $(\mathrm{n}=64$; present $=1950 \mathrm{CE})$ with 2-sigma error in chronological order. Labels show 11 mean pooled ages that represent times when two or more charcoal fragments from different sub-basins demonstrate statistically indistinguishable age distributions $(\alpha=0.05)$. Bottom graphs show four summed fire probability distributions. Lower basin fires (red curve) represent drier sagebrush steppe-grassland basins; the upper basin fires (blue curve) represent wetter, densely forested basins; and the total MFSR fires (black curves) include fires from all basins. The lower total MFSR fire curve was detrended using the method of Surovell et al. (2009). Inverted bar graphs represent the number of weighted mean ages within each 50-year time interval. The colored circles on peaks on the detrended MFSR total fire curve correspond to multi-basin fires described in the legend. Red bars are samples from lower basins and blue bars are from upper basins. 


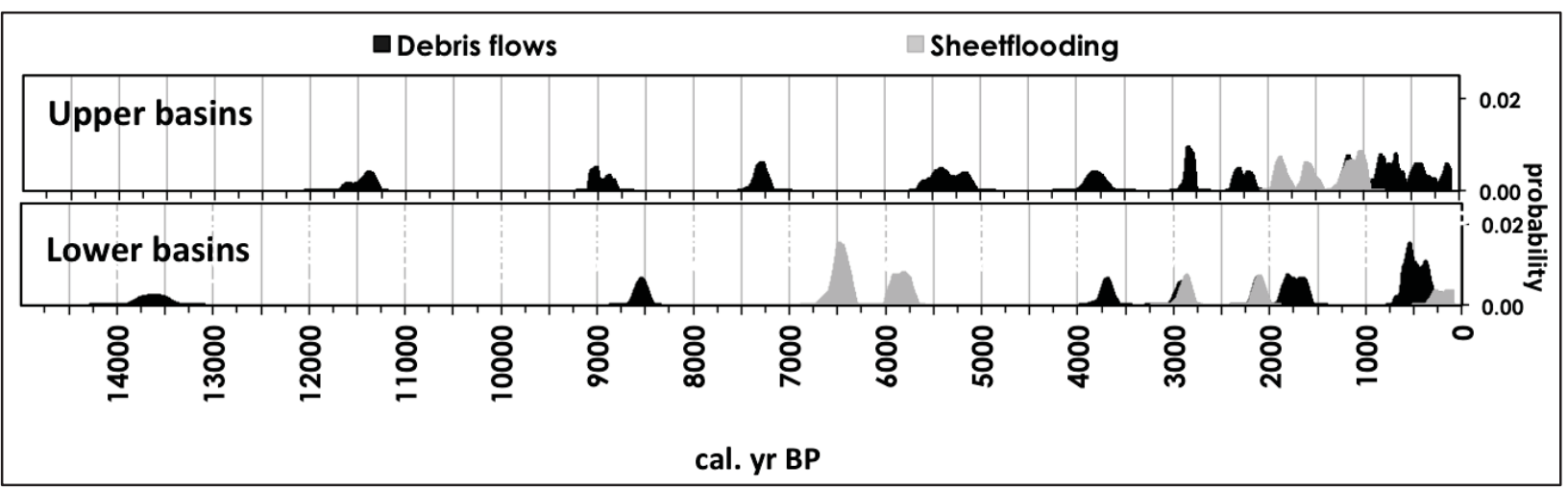

Figure 4: Probability density distributions for calibrated ${ }^{14} \mathrm{C}$ ages on fire-related deposits, classified by depositional process, grouped into upper and lower tributary sub-basins, and summed as described in text.

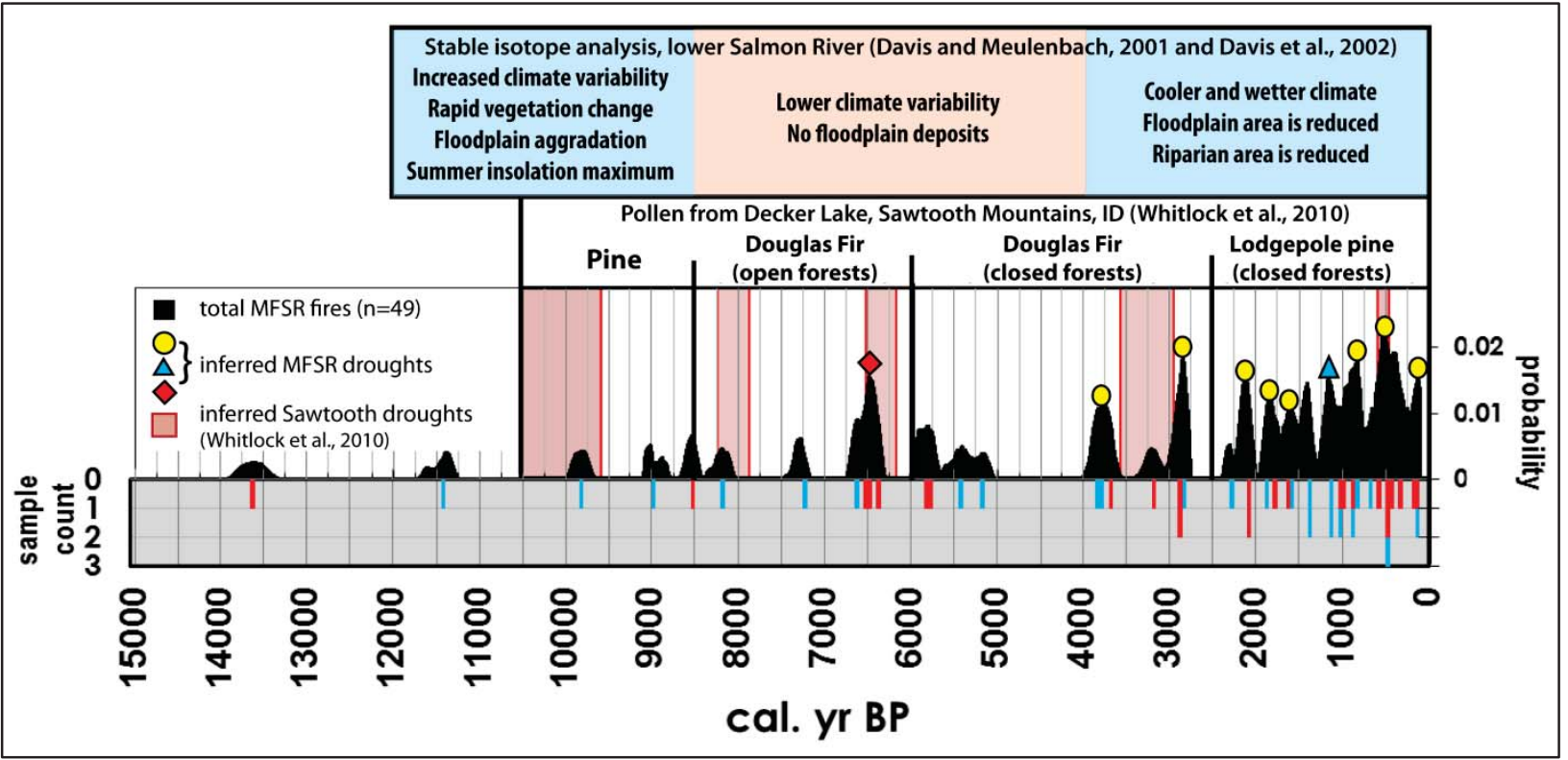

Figure 5: The fire record from the MFSR in black, with histogram of ages in the inverted bar graph for upper (blue) and lower (red) basins. Circles, triangles, and diamonds represent times with $\geq 2$ statistically indistinguishable firerelated deposit ages from multiple basins, inferred to stem from regional drought; blue triangles represent multiple upper basin fires, red diamonds multiple lower basin fires, and yellow circles represent fires in both upper and lower basins. Generalized interpretations from regional paleoenvironmental proxy records are shown at top. 


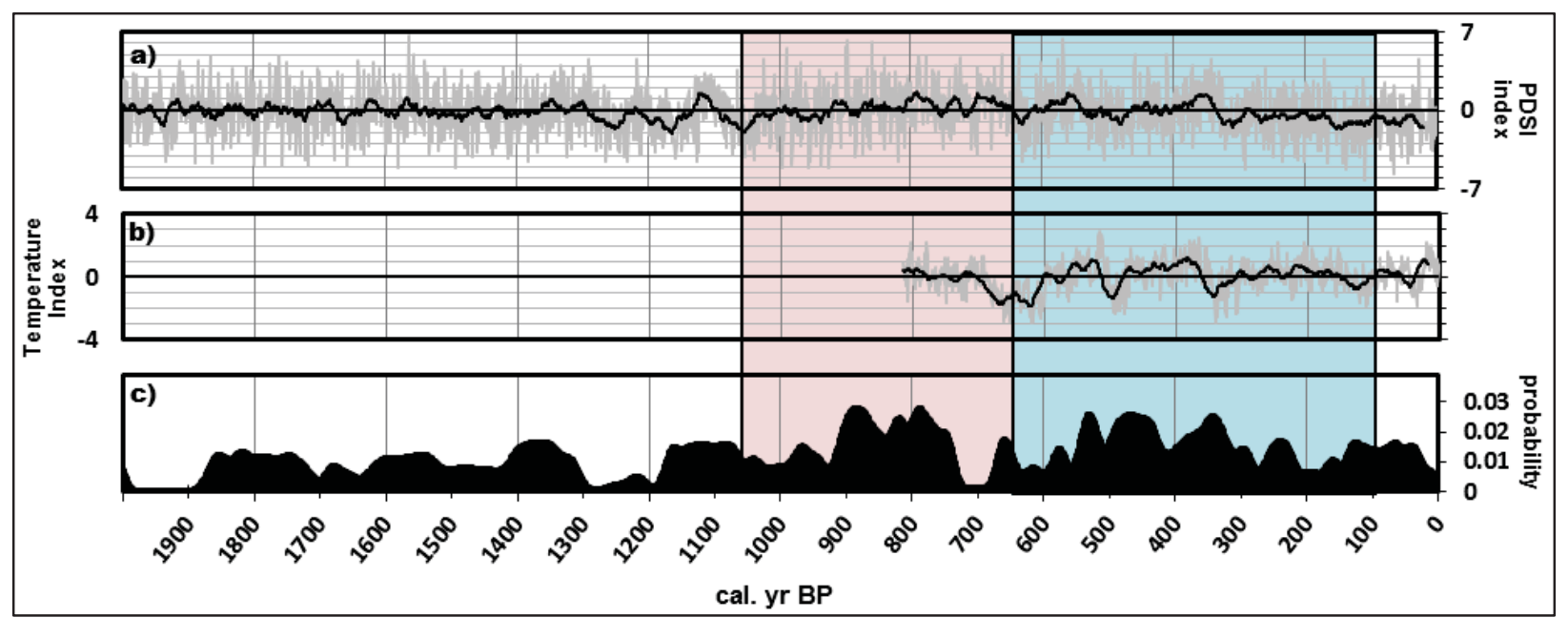

Figure 6: MFSR fire record for the last $2000 \mathrm{yr}$ compared with tree-ring paleoclimate reconstructions. Blue shading represents the Little Ice Age (LIA) and the red shading represents the Medieval Climatic Anomaly (MCA). a) North American summer Palmer Drought Severity Index (PDSI) reconstruction for gridpoint 69 (Cook et al., 2004). A 20year running mean (black line) is applied to the annual reconstruction (grey line). Y-axis is the PDSI value where values $<-4$ indicate extreme drought and $>+4$ indicate extremely wet conditions. b) East-central Idaho July temperature reconstruction (grey line; Biondi et al., 1999) with a 10-year running mean (black line). Y-axis is temperature departure from the long-term mean in standard deviation units. c) MFSR fire reconstruction for the last 2000 years 